\title{
HOMENAGEM AO PROFESSOR NEWTON DE LUCCA
}

\author{
Cândido Rangel Dinamarco \\ Professor Titular de Direito Processual da Faculdade \\ de Direito da Universidade de São Paulo
}

Prezados amigos meus e do Newton de Lucca. Nesta manifestação muito cordial e avessa a formalismos, não vou saudar advogados, magistrados, ministros, desembargadores, não vou saudar promotores de Justiça, professores ou senhoras e senhores. Saúdo somente, como já fiz ao começar, os nossos amigos.

Vou falar do Newton de Lucca falando também de mim mesmo, falando da nossa Faculdade e falando da figura do professor. Você é um professor completo, porque reúne todos os predicados para sê-lo.

Ser professor é, em primeiro lugar, gostar de dar aulas. Você gosta. Há quanto tempo convivemos na sala dos professores e você sempre aí, entusiasmado com o que faz, discutindo temas, buscando meios de melhor transmitir conhecimentos. Sou também testemunha indireta (indireta, mas testemunha) de seu comportamento $\mathrm{cm}$ aula, aplicado e disponível para os alunos, disposto a responder, a orientar, a explicar melhor o que não houver sido bem compreendido.

Sou testemunha, porque nos já distantes anos de 1985 e 1986 um de meus fïlhos foi seu aluno e recebeu de você todas essas atenções e até hoje relembra scu cntusiasmo pelos temas que desenvolve em sala. Ele herdou de você, Newton, entre outras coisas, o seu gosto pela teoria dos títulos de crédito e uma sólida formação quanto aos temas básicos de seu Direito Comercial.

Mas não basta gostar. Ser professor é também dar boas aulas. E isso você faz com maestria, com clareza de exposição, com coerência em seus pensamentos, com segurança quanto aos conceitos. Lembra-se, Newton, do Curso de Direito Falimentar que conduzimos juntos em 1990, com a participação do professor Edoardo Ricci, da Universidade de Milão? Ficávamos todos atentos e fascinados pela naturalidade e destreza com que você conduzia suas exposições, depois da exposição do convidado, demonstrando profundo conhecimento do Dircito de nosso País e também do sistema concursal italiano, causando nos espectadores um sentimento da mais profunda admiração e esclarecendo dúvidas de Direito Comparado que não seriam bem compreendidas sem o aporte de suas lições. 
Mas ser professor é ainda mais do que isso. O mestre-escola que apenas transmite idéias, cumpre também uma missão de grande relevância, mas não é um professor completo. Mas você cria, Newton. Você inova. Você interfere na doutrina dos antepassados e dos seus mestres, propondo idéias novas, modernizando a doutrina. Quem como você se dedica à teoria dos títulos de crédito e quantos se interessam pelo moderníssimo tema Direito e Internet? Ser professor é também ser um desbravador de mares nunca dantes navegados - e você o é, Newton.

Mas o professor que gosta do que faz, que ensina com entusiasmo, que orienta alunos com aplicação, que sabe desenvolver e modernizar pensamentos vindos do passado, que traz propostas novas e coerentes, ainda não será um professor maiúsculo se não tiver persistência. E você persiste, Newton. Há trinta anos você está ali, há trinta anos fazendo exercícios de insistir no que vinha dizendo desde o começo e de rever pensamentos que não mais o convencem. Há trinta anos? Não. Há mais de trinta anos.

Você mesmo gosta de lembrar o tempo em que ainda era estudante do quinto ano da Faculdade e eu um assistente que principiava seus passos na carreira de processo civil. Isso foi em 1971. Levado às primeiras experiências docentes pelas mãos do professor Luís Eulálio de Bueno Vidigal, lá estava eu, ora substituindo algum professor que faltasse, ora realizando seminários, sempre querendo aproveitar bem a oportunidade que me havia sido dada pelo inesquecível mestre.

E você gosta de lembrar sempre aquelas minhas primeiras experiências como jovem professor principiante, inclusive com uma audiência simulada que conseguimos montar em minha residência, então em uma casa no elegante bairro do Brooklin Paulista. Aquilo foi importante para você? Acho que foi, mas tenha a certeza de que foi muito mais importante para mim. A riqueza de nossa Escola reside na capacidade de perenizar-se no tempo, em uma dinâmica incessante que impulsiona jovens idealistas e lhes abre caminho para, de repente, de aluno fazer-se mestre. Nós dois somos frutos dessa dinâmica e dessa capacidade, que a Faculdade do Largo de São Francisco sempre teve, de manter-se viva na vida de seus próprios filhos.

Estou falando da grande utilidade dos docentes voluntários na dinâmica histórica da vida da Faculdade. Por mais que a demagogia irracional dos regimentos burocráticos venha a execrar a figura dos docentes voluntários, eles são um elo entre o passado e o futuro, como nós dois fomos e como foram praticamente todos os grandes mestres da nossa Escola. Assim como o professor Bueno Vidigal me acolheu e estimulou, 
um outro grande mestre das Arcadas também sentiu desde logo as luzes do seu talento e da sua vocação.

Foi assim que, ainda recém-formado, já no ano de 1972 você começou a auxiliar o saudoso professor Filomeno Joaquim Costa, o Velho Filó, como carinhosamente ainda nos referimos a ele, o qual chamou aquele menino para auxiliá-lo nas aulas de Direito Comercial. E o menino aqui está, agora crescido e com toda a maturidade de seus trinta anos de docência, com um passado de escritos, de idéias e de talento, mas sempre com o entusiasmo de menino que o impulsionara a principiar.

É por isso que, como disse no início, eu não seria capaz de falar de você sem falar de mim mesmo. Cheguei a ficar surpreso, quando me dei conta de que aquele menino, que de algum modo fora meu "aluno", acaba de chegar aos seus trinta anos de docência acadêmica. Vejo que, apesar dos dez anos de diferença em nossas idades, nós praticamente principiamos juntos. Somos frutos do mesmo espírito de continuidade da nossa Escola e de sua perene e inextinguível vocação à sobrevivência histórica. Assim como trago sobre os ombros um rico passado representado por Vidigal e Liebman em sua vivência nas Arcadas de São Francisco, você também se confunde com as grandes figuras do Direito Comercial da Casa. Você se insere entre os grandes nomes do presente, no lavor de levar adiante a sólida tradição instituida pelos fundadores Waldemar Ferreira e Tullio Ascarelli, passando por Honório Monteiro, Sílvio Marcondes e Filomeno da Costa.

Como anunciei, também, estamos falando da nossa Faculdade. O que ela espera de nós, como professores que pretendem ser mais que meros mestres-escola, é uma visão do passado e do futuro, capaz de nos impulsionar a nos perpetuarmos em nossos discípulos, porque isso é perpetuar as tradições culturais do próprio Largo de São Francisco. Quero proclamar aqui, solenemente, como inúmeras vezes venho proclamando, o meu intuito e o meu empenho, que já são muito antigos e que também são seus, de formar jovens docentes. Essa é uma imensa responsabilidade, que assumimos, quando nos tornamos professor, tendo a consciência de que não exercemos nossas funções para proveito de nossos próprios projetos de vida, ou de nossas vaidades pessoais, mas para produzir algo de interesse de nossas ciências.

E agora comemoremos. Comemoremos a nossa Faculdade, que tem o Newton de Lucca há trinta nos, comemoremos o nosso entusiasmo em lecionar, em criar, em perenizar. Comemoremos também a sua poesia, Newton, que é a linguagem da sua alma e mensagem que ao mesmo tempo enternece e liga você com a vida que 
o cerca e com as pessoas que ama. Comemoremos, afinal, sua capacidade de amar e de ser amado, que é a maior de todas as razões pelas quais aqui estamos, festejando os scus trinta anos de docência acadêmica e a amizade que nos une. Que Deus nos mantenha sempre amigos como hoje somos e conserve a perene estima que lhe dedicam os amigos aqui presentes para homenageá-lo. 